\title{
OS SÍMBOLOS SOCIAIS NO VODU HAITIANO E SEUS SIGNIFICADOS ${ }^{1}$
}

\section{SOCIAL SYMBOLS IN HAITIAN VOODOO AND THEIR MEANINGS}

\section{Nikita Suire}

nikitasuire@gmail.com

Graduada em Antropologia/Sociologia na Faculté d'Ethnologie (FE) da Université d'État d'Haiti (UEH), Mestre pelo Programa de Pós-graduação em Cultura e Sociedade (PGCult) na Universidade Federal do Maranhão (UFMA)

ORCID: https://orcid.org/0000-0002-9683-651X

\section{Flávio Luiz de Castro Freiras}

f_lcf@hotmail.com

Professor Permanente do Programa de Pós-Graduação em Cultura

e Sociedade-PGCULT/UFMA - Universidade Federal do Maranhão (UFMA)

Docente do Curso de Licenciatura em Ciências Humanas/Filosofia ORCID: https://orcid.org/0000-0002-7648-0341

\section{Ana Caroline Amorim Oliveira}

ana.caroline.oliveira@gmail.com

Professora Permanente do Programa de Pós-Graduação em Cultura e Sociedade-PGCULT/UFMA - Universidade Federal do Maranhão Professora do Curso de Licenciatura em Ciências Humanas/Sociologia ORCID: https://orcid.org/0000-0002-9337-6335

\section{(C) $\odot \Theta(0)$}

Esta obra está licenciada sob uma licença Creative Commons Attribution-NonCommercial-ShareAlike 4.0 International License.

\section{RESUMO}

Este artigo trata sobre a religião vodu, em especial os símbolos sociais sagrados do vodu haitiano e seus significados simbólicos. Para isso é necessário compreender como se estabeleceu a relação entre o vodu e o cristianismo. Esta religião, trazida pelos colonizadores, realizou uma perseguição à religião vodu e seus adeptos, tentando se impor como "a" religião da civilização. Nesta relação tensa ocorreram mudanças e sincretismos entre as duas religiões, que podem ser identificados nos símbolos sagrados do vodu. Esses objetos sagrados são carregados de significados e dotados de poderes. Nossa pesquisa será de abordagem etnográfica, com base na análise e interpretação dos documentos selecionados, os quais já estão inseridos em nosso tema de pesquisa. Tais objetos sagrados são significados pelos seguidores do vodu enquanto 
resistência identitária e política contra as imposições e repressões feitas tanto contra o vodu quanto seus adeptos, garantindo a sua transmissão de uma geração para outra. A sacralização dos objetos feitos pelos seguidores do vodu serve como o início de sua construção não apenas enquanto resistência do vodu contra várias repressões feitas contra ele, mas também da sobrevivência do vodu haitiano.

Palavras-chave: objetos sagrados; vodu haitiano; sincretismo.

\begin{abstract}
This article deals with the Voodoo religion, in particular, the sacred social symbols of Haitian voodoo and their symbolic meanings. For that, it is necessary to understand how the relationship between Voodoo and Christianity was established. The latter was introduced by the colonizers, and it provoked a persecution over the Voodoo itself and its followers, trying to impose itself as "the one and only" religion of civilization. In this tense relationship, there were changes and syncretism between the two religions, that can be identified in the sacred symbols of Voodoo. These sacred objects are full with meanings and power. Our research will have an ethnographic approach, based on the analysis and interpretation of the selected documents, which are already included in our research theme. Such sacred objects are signified by the followers of voodoo as identity and political resistance against the impositions and repressions made against them and their religion, guaranteeing its transmission from one generation to another. The sacralization of objects made by the followers of voodoo serves as the beginning of their construction, not only as resistance against various repressions made against it, but also the survival of Haitian voodoo.
\end{abstract}

Keywords: sacred objects; haitian voodoo; syncretism.

\title{
INTRODUÇÃO
}

O vodu haitiano sofreu ao longo de sua formação um processo de demonização. Esse se deu pelo ato de transformar, literal ou figurativamente, seus atores em forças do mal, personificadas em um ser com o qual toda conciliação é, em essência, impossível e repreensível (CORTEN, 2000). Durante vários períodos da história do Haiti, o vodu seria considerado uma religião do diabo. Este processo começou com a consideração da negritude do povo negro, na era colonial, como símbolo de decadência, proximidade com o diabo, desordem e violência absolutas, algo que depois se tornou oficial, com a promulgação do código negro de Luís XIV, em 1685, em Santo Domingo (nome dado ao Haiti durante o período colonial). 
Colocar o rótulo de superstição no vodu foi uma das formas que o cristianismo adotou para excluir o vodu no Haiti. Este processo de exclusão é especialmente marcado pela imposição de outras tradições nos costumes dos haitianos, que estão intimamente relacionados ao vodu, porque o vodu é: “O conjunto de fenômenos psicológicos referidos como crenças popular, que são técnicas e conceitos jurídicos, devaneios de teosofistas, práticas de médicos” (MARS, 1928, p. 39). Às vezes, essa imposição é feita por meio de aprendizado, medo e até mesmo violência física, em alguns casos.

No entanto, apesar da perseverança do cristianismo desde a era colonial contra o vodu, apesar da sua demonização e qualificação de superstição, o processo de demonização do vodu haitiano ainda está incompleto até hoje. Os voduístas mudam seu status de vodu para católico, mas sempre de maneira superficial. Acontece até de os haitianos duplicarem, fazerem um casamento dos santos do catolicismo e loas (deuses, espíritos vodu) vodu, daí o sincretismo do vodu haitiano (CLORMÉUS, 2014).

Este artigo trata sobre a religião vodu, em especial os símbolos sociais sagrados do vodu haitiano e seus significados simbólicos. Para isso é necessário compreender como se estabeleceu a relação entre o vodu e o cristianismo. Nossa pesquisa será de abordagem etnográfica, com base na análise e interpretação dos documentos selecionados, os quais já estão inseridos em nosso tema de pesquisa.

O artigo está estruturado da seguinte forma: primeiramente, apresentando o processo de perseguição da religião vodu pelos colonizadores através de leis e documentos oficiais (da metrópole e religiosos). Em seguida, analisamos o sincretismo que ocorreu entre as religiões cristã e o vodu como uma forma de resistência dos religiosos do vodu, e que pode ser identificada nos seus símbolos sagrados. Logo depois, apresentaremos os objetos sagrados e seus significados. Por fim, as considerações finais.

\section{DEMONIZAÇÃO DAS RELIGIÕES AFRICANAS E CRISTIANIZAÇÃO DOS AFRICANOS}

O processo de demonização e cristianização das religiões africanas em seu continente prefigura a cristianização dos escravos e a demonização das religiões africanas no Santo Domingo. Segundo Thornton (1998), no reino de Allada (comumente conhecido como Arada, na costa do Daomé) e suas áreas adjacentes, a cristianização dos africanos era indireta.

O clero missionário e os cristãos leigos procuraram converter os habitantes e difundir os ideais cristãos. Na região de Fon - região da África Negra, de onde partiram muitos dos que comporão a população escrava em Santo Domingo durante a colonização francesa do Haiti -, alguns membros da elite estudaram na Europa, e um número bastante 
grande deles foi para São Tomé, outra área próxima, onde receberam instrução religiosa.

Além disso, os missionários cristãos favoreceram o processo de assimilação do cristianismo nessas regiões, traduzindo o nome de Jesus no Catecismo de 1658, dando-lhe o nome de Lisa - nome de uma divindade no vodu [Daomé] -, que representa dois aspectos: um preto e feminino: Mawu, e um branco e masculino: Lisa (LABOURET; RIVET, 1658 apud THORNTON, 1929).

Ao contrário do reino de Allada (Arada) e seus arredores, a cristianização no Congo foi um pouco mais grosseira. Os europeus já usavam os termos "superstições" e "demonização" para caracterizar as práticas religiosas dos habitantes dessa região. Por exemplo, no Congo, as revelações feitas por negros eram demonizadas e consideradas feitiçaria. Castelo de Vide, citado por Thornton (1998, p. 88), nos relata que "As revelações feitas ao ngangan eram consideradas feitiçaria, no sentido europeu da palavra, isto é, uma aliança com o diabo com bons ou maus fins" - ngangan é o nome dado aos sacerdotes vodu no Congo.

Os escravos que habitavam a colônia de Santo Domingo eram esmagadoramente de origem das regiões Fon, Mahi, Nago, Arada, Congo, Wolof, Angola, entre outras (MÉTRAUX, 1958). Daí a importância de mencionar a cristianização, bem como a demonização das religiões africanas nessas regiões mencionadas. Chegados à colônia, suas práticas religiosas e culturais muito contribuíram para a formação do atual vodu haitiano.

Quando os escravos chegaram a Santo Domingo durante o comércio de escravos, foi quando o vodu haitiano, propriamente dito, fez sua estreia no período colonial francês, o que significa uma extensão da cristianização dos negros da África, assim como das suas práticas religiosas, que já eram consideradas como "feitiçaria".

A escravidão dos negros, em si, era considerada um privilégio dos colonos com o objetivo de "civilizá-los" e cristianizá-los. Assim, para os colonos, os escravos eram pagãos que deveriam ser convertidos ao cristianismo, a fim de passar do estado de "selvageria" para o estado de "civilização" (HURBON, 1975).

Com acusações de bruxaria $^{3}$ e crime, a escravidão negra também foi justificada pelos colonos como um favor feito aos negros para estes não serem mortos, e um alívio dos escravizados desalojados de seu continente (África), antes privados da cultura da civilização. Assim, Padre Labat, em 1705, afirma que: "Quase todos os negros que saem de seus países são bruxas, ou pelo menos eles têm algum tingimento de magia, feitiçaria e veneno" (apud HURBON, 1975, p. 20). Na mesma linha, Émilien Petit afirma em 1771 que:

Os negros que são exportados das costas da África são ou prisioneiros, ou criminosos destinados a morrer pela lei dos mais fortes, e reservados para o comércio em vez de matá-los, ou escravos nativos, em que os 
senhores ou os reis têm direito à vida e à morte [...] (apud HURBON, 1975, p. 11).

Sempre no contexto de um suposto favorecimento aos negros, desalojando-os da África, do chamado estado "bárbaro" para o chamado estado "civilizado" e removendo suas "superstições". Os africanos transportados para as Américas também foram considerados inferiores aos brancos por causa de sua cor de pele. Assim, para Jules Ferry, a questão racial parece o segundo ponto da escravidão negra.

A questão colonial é para os países dedicados pela própria natureza de sua indústria a uma grande exportação, como a nossa, a questão dos mercados. Mas há um segundo ponto, é o lado humanitário e civilizador da questão. Deve ser dito abertamente que as raças superiores têm direito às raças inferiores (apud HURBON, 1979, p. 64).

Os missionários e colonos apelaram para as crenças sobre bruxaria prevalecentes na Europa para fazer crer que os africanos eram um grupo de pessoas nascidas sob o reinado da maldição e vivendo totalmente sob a influência do diabo, a maldição de $\mathrm{Cam}^{4}$. Na Bíblia, este representaria a população da África Negra e, como ele foi amaldiçoado, está condenado à escravidão; alguns missionários reivindicaram explicar assim $\mathrm{o}$ consentimento dos negros, como posteridade de Cam, à escravidão (HURBON, 2005).

Não se poderia falar sobre a formação do vodu haitiano sem mencionar o marronage dos escravos. Foi um dos elementos fundamentais da construção sociorreligiosa no Santo Domingo. Ele desempenhou o papel de ligação entre diferentes culturas africanas, o que levaria à formação de uma cultura comum e negra, vodu, e a uma nova língua, o crioulo. Marronnage no começo era simplesmente um meio de sobrevivência para os escravos, mas seria cada vez mais organizado e objetivo.

[O] Vazamento coletivo [marronnage] fora das plantações e oficinas será sistematicamente organizado. De agora em diante, podemos ver uma reconstrução da vida africana como a simples restauração da continuidade com a África perdida. Estamos de fato na presença de uma recriação, uma readequação de costumes, crenças e práticas religiosas e culturais, tão completamente novas (HURBON, 1975, p. 15).

Assim, surgiu o vodu de arrumação, assim como os costumes matrimoniais e outros costumes africanos que se reajustariam a uma cultura dos negros de Santo Domingo, como o lakou ${ }^{5}$ e combite ${ }^{6}$, o remédio das folhas ${ }^{7}$. Uma multidão de contos e organizações familiares relacionadas às culturas africanas também estavam surgindo, sobre as quais Hurbon fala de uma nova maneira de retomar e reler as mitologias e crenças africanas sob a influência das novas condições de vida da escravidão (HURBON, 1975).

Todos esses legados citados acima estão de acordo com Verschueren (1948, p. 335), pois, para ele, o vodu é tão “[...] inextricavelmente 
entrelaçado no quadro da vida do haitiano, em suas ideias sobre o mundo, suas relações social e familiar, seus preconceitos e peculiaridades, que não podemos entender este povo sem este culto".

O vodu foi demonizado durante vários períodos da história do Haiti. Um processo que começou com a consideração da adoração de deuses e das práticas religiosas dos negros, nos tempos coloniais, como idolatria e proximidade com o diabo. Esse processo continuou com a vontade dos colonos e de alguns padres católicos de converter escravos e haitianos ao cristianismo, a fim de levá-los do chamado estado "bárbaro" ao chamado "estado civilizado".

As proibições e perseguições contra o vodu haitiano apareceram durante o período colonial francês, quando o rei Luís XIII estava disposto a "salvar" os africanos do que ele denominava de idolatria e colocá-los no que dizia ser o bom caminho para eles poderem voltar ao serviço do chamado verdadeiro Deus, e praticar a chamada religião verdadeira - o cristianismo. "Para inspirar a adoração do verdadeiro Deus aos africanos, retirá-los da idolatria e perseverá-los até os mortos na religião cristã, que eles serão obrigados a abraçar". Esta foi a declaração desse rei da França sobre a escravidão dos negros trazida pelo Padre JeanBaptiste Labat (apud HOFFMAN, 1987, p. 5).

A fim de preservar esta vontade, para evitar todas as formas de rebelião e para ter a submissão geral de escravos em suas colônias, o seu sucessor, Luís XVI, tomou certas medidas, incluindo o Código Negro, que em seus artigos $2^{\circ}$ e $3^{\circ}$ resolve a questão da religião entre os escravos, impondo-lhes o catolicismo e proibindo suas religiões nativas. Estes artigos estipulam sucessivamente:

Todos os escravos que estarão em nossas ilhas serão batizados e educados nas religiões católica, apostólica e romana. Peçamos aos habitantes que compram negros recém-chegados que informem o governador e o administrador das referidas ilhas pelo menos oito dias depois, sob pena de multa arbitrária, que dará as ordens necessárias para que sejam instruídos e batizados no devido tempo. (LOUIS XVI, 1680, p. 7)

Proibamos qualquer exercício público de outras religiões além da católica, apostólica e romana; queremos que os criminosos sejam punidos como rebeldes e desobedientes aos nossos mandamentos; proibir todas as assembleias para esse fim, que declaramos conventuais, ilícitas e sediciosas, sujeitas à mesma punição que ocorrerá contra os senhores que permitirão ou sofrerão com respeito a seus escravos. (LOUIS XVI, 1680, p. 7).

Não foi a única precaução tomada pelos colonos na época para combater o vodu. Em 1704, um decreto proibiu os escravos de "fazerem reuniões noturnas sob o pretexto de danças gerais” (MÉTRAUX, 1958, p. 26). Em 1765, foi criada, como a primeira legião de Santo Domingo, um corpo de tropas de luz. Foi designado como sua função dissipar as assembleias e calendas dos negros (MÉTRAUX, 1958) - as danças de 
cerimônias de vodu na época da colonização francesa do Haiti, durante as quais os escravos aprenderam a manter a confiança mútua entre eles. Esta palavra não é mais usada no vodu haitiano (HURBON, 1975).

As lutas contra o vodu haitiano não se limitaram apenas às prioridades dos colonos e do período colonial. Elas duraram durante e mesmo depois da Independência do Haiti. Alguns generais negros também lutaram contra o vodu. Este foi o caso de Toussaint Louverture, Jean-Jacques Dessalines, Henri Christophe e Nicolas Fabre Greffrard, que são figuras importantes nas lutas que levaram à independência do Haiti em 1 de janeiro de 1804. Este é também o caso do presidente Élie Lescot, alguns padres da Igreja Católica e o presidente Sténio Vincent, sob a ocupação americana que ocorreu de 1915 a 1934 no Haiti.

Toussaint Louverture, na época em que se proclamou governador, conforme Constituição publicada em 1801, rejeitou o vodu para reconhecer o catolicismo como religião oficial. Nessa Constituição, o artigo $6^{\circ}$ declara que: "A religião católica, apostólica e romana é a única publicamente professada" (MÉTRAUX, 1958, p. 29). Além disso, ele proibiu todas as danças ligadas ao vodu, sob pena de sanções. Neste termo, Hoffmann relatou:

A partir do dia da publicação deste, todas as danças e todas as reuniões noturnas serão proibidas. Nas cidades, bem como nas várias moradas das montanhas e da planície, castigos corporais serão infligidos àqueles que, desafiando esta defesa, infligirem danças ou realizar assembleias noturnas; eles serão encarcerados e serão devolvidos a mim por aqueles que ordenaram sua prisão (HOFFMANN, 1987, p. 23).

Dessalines, o inspetor-geral no departamento oeste do Haiti, nomeado por Toussaint em 1804, também atacou o vodu. Sobre este fato, o historiador haitiano Thomas Madiou relatou uma busca por seguidores de vodu liderada por Dessalines:

[...] Ele [Dessalines] relatou que muitos desses magos chamados vodu encontraram-se na planície de Cul de Sac; que na cabeça dessa banda havia uma velha negra e que um grande número de fazendeiros estava deixando os campos para ir ao local onde a feitiçaria foi feita. Ele veio com um batalhão da $8^{\mathrm{a}}$ [brigada semimilitar] na planície de Cul de Sac, cercou o local onde os vodu estavam reunidos, atirou na cabana, dispersou-os e matou cinquenta com golpes de baionetas (MADIOU 1848 apud HOFFMAN, 1987, p. 24).

Christophe também desprezou o vodu. Em sua desaprovação do vodu, o general Guyjoseph Bonnet relata que "o rei [Christophe] foi reprimido por superstições terroristas da África, e continuou com culto excessivo de vodu e as práticas terríveis" (BONNET, 1864 apud HOFFMAN, 1987, p 24). Sobre o mesmo assunto, Hénock Trouillot escreveu, citando uma carta inédita de Christophe:

Christophe atraiu, no final de [...] 1805, a atenção do Major-General 
Capois nas danças de vodu [...] organizadas no noroeste do Haiti. Pediu-lhe que evitasse "uma dança tão prejudicial à tranquilidade. Seria necessário não só impedir essa dança, que sempre foi defendida por todos os governos, mas deter os organizadores" (TROUILLOT apud HOFFMAN, 1987, p. 24-25).

O vodu não descansará sob a ocupação americana. Sob o governo de Sténio Vincent, nessa altura, um decreto-lei foi publicado por este, em que tudo o que se relacionava com o vodu era proibido. Neste decreto lemos:

Art.1. As seguintes são consideradas práticas supersticiosas: a) cerimônias, ritos, danças e reuniões em que sacrifícios de gado ou aves são oferecidos como oferenda às chamadas divindades; b) explorar o público mostrando que, por meios ocultos, é possível mudar a situação de riqueza de um indivíduo ou curá-lo de algum dano por meio de métodos ignorados pela ciência médica; c) ter em sua posse objetos cabalísticos para explorar a credulidade do público.

Art.2. Quem estiver convencido destas práticas supersticiosas será condenado a seis meses de prisão e multa de quatrocentos gourdes, todos a serem pronunciados pelo Tribunal de polícia.

Art.4. Os itens usados para cometer a infração definida na seção 2 serão confiscados (VERSCHUEREN, 1948, p. 334).

Quanto à perseguição ao vodu no Haiti por padres católicos, ela se firmou especialmente com a assinatura da concordata de Damien, um acordo assinado entre a Santa Sé e o governo haitiano em 1860. Essa assinatura dava à Igreja Católica direito de civilização sobre os indivíduos que praticavam o vodu. Como resultado, o código penal desse período, em seus artigos 405-407, deu o direito de castigar qualquer crime conhecido como superstição, ou seja, qualquer ato religioso que vai contra a Igreja Católica (HURBON, 1972). O artigo 405 do Código Penal estipulava:

Todos os fabricantes de wangas $^{8}$, capreletas $^{9}$, vodu, dompèdre ${ }^{10}$, macandals ${ }^{11}$ e outros feitiços serão punidos com três meses a seis meses de prisão e multa de 60 gourdes $^{12}$ a 150 gourdes pelo tribunal da polícia simples, e em caso de reincidência, de prisão de seis meses a dois anos e multa de 300 gourdes a 100 gourdes, pelo tribunal penal, sem prejuízo das penas mais pesadas em que incorreriam por causa dos crimes, ou crimes por eles comprometidos em preparar ou cumprir seus feitiços.

Todas as danças e outras práticas que serão de natureza a manter nas populações o espírito de fetichismo e superstição serão consideradas como feitiços e punidos pelas mesmas penalidades (RÉPUBLIQUE D'HAÏTI, 1860).

A Igreja Católica também contribuiu para difundir a ideia de que praticar o vodu tem um caráter degradante e desonroso para 
a civilização. Durante muito tempo, os sacerdotes mencionaram o vodu em termos de macaquerie ${ }^{13}$ indigna de um povo civilizado. E promoveram a campanha antissupersticiosa ${ }^{14}$ [1896-1900], chamada de operação de limpeza, na qual os anti-vodu teriam que destruir tudo o que fosse relacionado ao vodu, isto é, quebrar as garrafas, jarros, rasgando imagens, rasgando e queimando polos (poteaux-mitan) ${ }^{15}$ e cruzas, tirando pedras, removendo colares, esmagando os cayes-loa ${ }^{16}$, cortando madeiras servidas, profanando tudo que é sagrado para os seguidores do vodu (HURBON, 1972).

Durante esta campanha, a Igreja Católica não se deteve apenas nas profanações dos objetos sagrados do vodu: alguns padres católicos escreveram relatórios e pregaram contra o vodu. É o caso de alguns relatos do bispo Jean-Marie Kersuzan e do relatório do padre Pascal, dirigido ao ministro da religião, em 1861, no qual demoniza e descreve o vodu como uma "superstição" e uma "barbárie" que deve ser abandonada, devendo em seu lugar abraçar o catolicismo e entrar na civilização. Em uma carta pastoral, o bispo Kersuzan prega o abandono do vodu em favor do cristianismo, enquanto demoniza o vodu e denuncia os indivíduos que praticam as duas religiões ao mesmo tempo:

Desde o início, os missionários certamente não deixaram de ensinar a incompatibilidade da superstição com a prática da religião cristã. A fé católica exige, como condição indispensável, uma ruptura com o paganismo, e para ser católico, o vodu deve necessariamente ser abandonado. Essas pessoas afirmam ser cristãs e frequentam os sacramentos, e não têm medo de participar (em práticas pagãs), como se pudessem servir a Jesus Cristo e ao Diabo. Que vergonha para estes infelizes! (apud HURBON, 1972, p. 22)

Padre Pascal, em um relatório dirigido ao ministro da religião, em 1861, propôs:

"Moralizar e civilizar a República do Haiti", "abolir o vodu" para acabar com os "encontros diabólicos" que são prejudiciais ao "progresso do Evangelho" e à "tranquilidade do país". [Para ele] é onde as conspirações são traçadas, é lá que os cultos idólatras ainda são honrados (apud CLORMÉUS, 2012, p. 105).

Houve uma segunda campanha antissupersticiosa liderada por católicos contra o vodu sob o governo de Elie Lescot em 19391942. Batizado como renúncia, assim como a primeira campanha antissupersticiosa, esta campanha, como o próprio nome sugere, foi focada em não desistir de catequizar os seguidores do vodu. Por esta razão, os partidários do catolicismo implementaram várias estratégias, incluindo o catecismo de 1941, usado durante esta campanha antissupersticiosa, e alguns livros de padres e fiéis católicos também foram escritos para o mesmo propósito no período. Neste catecismo, havia essas perguntas-respostas e esses juramentos: 
a) Quem é o principal escravo de Satanás? O principal escravo de Satanás é o Houngan ${ }^{17}$

- Qual é o nome que os houngans dão a Satanás? Os nomes que os houngans dão a Satanás são: $\operatorname{Loa}^{18}$, anjos, santos mortos, marassa ${ }^{19}$.

- Por que os houngans levam os nomes dos anjos, de santos e mortos para entregá-los a Satanás? Os houngans tomam os nomes de anjos, santos e mortos para entregá-los a Satanás para nos enganar mais facilmente.

- Como os houngans servem a Satanás? Por pecar, por fazer feitiços, por magia, por mangers-loa ${ }^{20}$, por mangers-les anges por mangers-marassa.

- Temos o direito de nos misturarmos com os escravos de Satanás? Não, porque eles são ladrões, eles são mentirosos como Satanás.

b) O juramento antissupersticioso

Eu, diante de Deus presente no tabernáculo, diante do Pai que o representa, renovo as promessas do meu batismo. Com a minha mão no Evangelho, juro nunca dar qualquer manger-loa, não assistir a qualquer cerimônia de vodu, nunca participar de um service-loa ${ }^{21}$ de forma alguma.

Eu juro que todos os fetiches e superstições da minha casa foram destruídos ou destruídos o mais rápido possível.

Em uma palavra, faço um juramento de nunca me dedicar a qualquer prática.

(Para pessoas casadas). Prometo ainda criar todos os meus filhos, sem exceção, na religião católica e romana, fora de toda superstição, submetendo-me plenamente ao ensinamento desta Santa Igreja (HURBON, 1972, p 21-22).

Sempre para fazer os seguidores do vodu renunciarem à sua religião, o padre Solasge escreveu um livro intitulado À la recherche d'un pastorale haïtienne, o que significa em português "Em busca de uma pastoral haitiana". No que diz respeito às cerimônias de batismo no catolicismo dos seguidores do vodu, neste livro, ele propõe este diálogo:

O padre: Você renuncia hoje e para sempre às práticas supersticiosas?

A renovação [A pessoa que batiza]: sim, com toda a minha força, desisto.

O padre: você renuncia à religião da África?

Renovando: sim, com toda minha força, desisto. (HURBON, 1972, p. 25)

Nas campanhas antissupersticiosas, os partidários do catolicismo não pararam apenas nas pregações e nos livros para tentar convencer os voduístas a abandonar sua prática religiosa. O medo também era usado como meio de persuasão, precisamente o temor de Deus e o medo do vodu. Desta forma, o padre Peters C. E., em seu livro intitulado Le service des loa, que se traduz em português por "O serviço dos Loa", disse: "Escusado será dizer que a idolatria material ou simulada que vem 
do medo é menos perniciosa do que a verdadeira idolatria que é baseada em perversidade do coração, mas permanece um grave pecado. Isto é acentuado pela Canon 1325” (apud HURBON, 1972, p. 23).

\section{SINCRETISMO CATÓLICO-VODU}

Vamos começar esta parte com a famosa frase colhida por Alfred Métraux durante sua etnografia sobre o vodu em Marbial, cidade localizada no sudeste do Haiti: "Você tem que ser católico para servir a loa” (MÉTRAUX, 1958, p. 287). Essa sentença nos faz entender que para cristianizar escravos e voduístas, as várias campanhas e lutas contra o vodu não foram desprovidas de consequências nas práticas do vodu no Haiti. Em alguns casos, elas reforçaram as práticas do vodu. Os seguidores do vodu conseguiram anexar certos rituais do catolicismo, apesar das diferenças entre essas duas religiões.

Segundo Verschueren (1948), os adoradores de vodu no Haiti transportam não apenas houmforts e costumes católicos para o vodu. Eles também tentam participar, tanto quanto possível, nas práticas religiosas da Igreja Católica, ao participar de festivais católicos, das missas, serem casados, comungados, batizados e confessados no catolicismo, e alguns deles até querem ter um funeral no catolicismo.

Os escravos e os voduístas podem não ter abandonado suas religiões, mas eles conseguiram se unir ao vodu e aceitar algumas práticas católicas para ampliar sua religião. Referindo-se sempre à etnografia de Métraux, um voduísta declarou: "Ele sempre seria fiel à Igreja Católica, mas nada no mundo o faria abandonar o culto de loa que protegera sua família" (MÉTRAUX, 1958, p. 287).

Ao repetir Jean Kerboul (1973), o sincretismo do vodu católico haitiano continua sendo, na maior parte, superficial. Os elementos emprestados do cristianismo são simples ofícios que não afetam a crença dos voduístas. Eles servem apenas como contêineres, mas não intervêm no significado original do conteúdo, que permanece em seu status quo. Tudo acontece como se excluindo a substância, o fenômeno do vodu é anexado aos rituais católicos romanos, que em nada afetam a sua originalidade.

"Todos os santos são loa, sem que todos os loa sejam santos" (MÉTRAUX, 1958, p. 289). Vamos continuar com essa analogia entre loa e santos, pois, como Milo Rigaud (1953) afirma, muitos santos católicos encontram seu alter ego no panteão do vodu. Para ele, essa analogia é uma espécie de astúcia entre os voduístas. Frequentemente perseguidos por sua religião, os voduístas concordam em honrar, mesmo em seu houmfort, os santos da Igreja Católica, representados na forma de certas estátuas da Igreja Católica Romana.

Graças à semelhança entre as representações físicas do loa e dos santos, bem como suas peculiaridades simbólicas, os adeptos do vodu unem as duas religiões usando essas estátuas para honrar o loa. Além de aproximar 
as duas, adorando estátuas que representam tanto loa como santos católicos, o sincretismo católico-vodu continua através do uso de certos lugares de peregrinação católica para adorar seus mistérios (RIGAUD, 1953).

Sem mais insistir nessa assimilação, em uma lista não exaustiva, as imagens católicas mais frequentemente adotadas pelos vuduístas são: a imagem da Virgem Maria, que representa o Erzuli loa por causa de sua beleza e pureza. O santo Jacques Majeur, descrito como um cavaleiro com uma armadura de ferro, é identificado com Ogou-Ferraille, o ferreiro e o guerreiro loa. Os santos católicos Lázaro e Antônio, que são retratados por homens idosos, representam o loa Legba, que também é um homem velho. Agoué, o marinheiro loa no panteão do vodu haitiano, é representado por santo Ulrich, o qual, em suas imagens para o catolicismo, tem um peixe na mão (MÉTRAUX, 1958).

Da mesma forma, para Michel Leiris (1953), as correspondências feitas entre as imagens dos santos católicos e os loa pelos seguidores do vodu haitiano são apenas superficiais e são apenas uma analogia de símbolos, que é feita de uma maneira puramente cíclica. No Haiti, as imagens usadas pelos voduístas haitianos são feitas na Itália e na Alemanha, então não é uma coincidência que representem santos. Assim explica Leiris:

É frequentemente um detalhe puramente circunstancial, e quase que poderia ser chamado de trocadilho, não de palavras, [...] de que a correspondência entre os santos e o loa é estabelecida; não é necessário, para estabelecer uma conexão, que haja uma analogia quanto ao conteúdo do símbolo: uma conexão superficial, fragmentária e, em suma, fortuita, parece suficiente em muitos casos (LEIRIS, 1953, p. 207).

A analogia feita pelos voduístas entre o loa e os santos católicos é marcada pela coabitação, a prática simultânea das duas religiões. Esta coabitação, que data da era colonial francesa do Haiti, é principalmente atribuída a dignitários católicos, como o bispo Jean-Marie Kersuzan, e os padres Peters C. E. e Jean-Baptiste Labat. Vamos começar com as causas dessa coabitação.

Como já dissemos, essa coabitação é datada do período colonial francês do Haiti, quando os escravos aparentemente só aceitavam o catolicismo que os colonos lhes impunham para evitar constrangimentos e conflitos sociais. Os escravos e os voduístas podem não ter abandonado suas religiões, mas eles conseguiram se unir ao vodu e aceitar algumas práticas católicas.

Como vimos acima, o bispo Kersuzan reprovou as pessoas que praticavam ao mesmo tempo as duas religiões. Assim foi também o caso do padre Peters e do padre Labat, este último fazendo a mesma censura aos escravos. Ele notou que com todo cuidado e com cada um de seus medos, os escravos apelavam a seus deuses (FOUCHARD, 1988).

Os colonos podem ter batizado e convertido os escravos ao cristianismo, mas os praticantes de vodu em Santo Domingo ainda 
encontraram tempo e maneiras, não apenas para os rituais religiosos católicos, mas também para sua religião. A esse respeito, o padre Labat escreveu:

[...] O fervor extraordinário com que um negro (mestres, sacerdotes) pediu o batismo e concordou em desistir de todos os pactos implícitos e explícitos que ele poderia ter feito com o diabo. Um domingo de manhã, o mesmo negro tem dois pássaros na mão, prontos para retornar às suas oferendas aos espíritos, como se, finalmente, o batismo tivesse sido para ele apenas um preâmbulo (apud HURBON, 1975, p. 21).

Pode-se concluir que, apesar do batismo imposto no catolicismo, nem os escravos nem o vodu "perderam" sua religião; forçados a adotar o cristianismo, eles o aceitaram, mas sem largar o vodu. $\mathrm{O}$ que o padre Peters denunciou neste texto:

[...] Ela [a Igreja Católica] teve que lutar contra o mal ainda mais, porque todos ou quase todos os seguidores do vodu eram seus filhos pelo batismo. Os servos do vodu, de fato, não constituíam um grupo de pagãos apenas ocupados com seu fetichismo, não tendo relações com a Igreja, mas foram e são batizados desconsiderando, ignorando e traindo a dignidade de seu batismo (apud HURBON, 1972, p. 23).

Como afirmam diversos autores, o vodu parecia se configurar como um idioma comum na socialidade haitiana, tão entranhado estava no caráter haitiano: "o caso singular do vodu e do Haiti permite-nos pensar a religião como um idioma, como uma linguagem através da qual são expressas as relações, na medida em que há profundas relações entre história, política, mitos e a própria constituição da nação [...]” (BAPTISTA, 2012, p. 275).

O sincretismo entre catolicismo e vodu não se encerra apenas com a prática das duas religiões simultaneamente, nem com a analogia entre santos e loa, mas vai até o uso de objetos sagrados e até mesmo rituais católicos pelos seguidores do vodu. Além da analogia entre os loa-santos, as imagens dos santos católicos são muito usadas no vodu. Sobre o uso de objetos sagrados católicos pelo vodu, um bispo da Igreja Católica (citado no livro Le vaudou haïtien, de Métraux, mas cujo nome não foi mencionado) denuncia o uso de imagens de santos católicos pelo vodu, para realizar suas práticas:

Eles [os seguidores do vodu] honra as imagens dos santos e pode-se até dizer que não há exceção entre os santos dos calendários, aqueles que não tiveram sua imagem importada para o país. Nas mentes do povo de vodu, a imagem que eles honram não representa mais este ou aquele santo, mas sim a divindade pagã que o substituiu e que, doravante, representa essa imagem através deles (MÉTRAUX, 1958, p. 289).

Ainda no contexto do uso de objetos sagrados católicos pelo vodu, um outro bispo (cujo nome também não é indicado no livro de Métraux) da Igreja Católica se queixou do roubo de anfitriões pelos seguidores 
do vodu, seguindo ordens de um padre de vodu, porque certos rituais vodus reivindicavam estes objetos católicos:

Há quem nos ensinou que muitas vezes as pessoas eram enviadas para a Mesa Sagrada para roubar a Sagrada anfitriã. Mas a comunhão da qual ele fala aqui envolve toda a reparação exigida pelo padre. E para obedecer à ordem da bòcor ${ }^{22}$, submeter-se-á a qualquer preço, a pessoa passará por qualquer teste: deve-se comunicar (MÉTRAUX, 1958, p. 292).

No mesmo contexto, o padre Labat já havia notado, na era colonial francesa, que os escravos (batizados no cristianismo) tinham uma grande fé na capacidade de curar e na proteção mística do pão abençoado e da água benta sobre eles, que os mantiveram e os usaram.

Todos os negros cristãos têm uma devoção muito grande e uma fé muito forte pelo pão abençoado neles. Eles comem, quando estão ruins ou quando temem algum perigo. Com relação à água benta, o que quer que seja feito no domingo em massa alta, é raro encontrar uma gota quando o culto termina; eles o carregam em pequenas calebasses ${ }^{23}$ e bebem algumas gotas quando se levantam e fingem se proteger com todos os feitiços que podem ser lançados sobre eles (MÉTRAUX, 1958, p. 291).

Como já assinalamos nos parágrafos anteriores, o sincretismo católico vodu no Haiti também ocorre por meio de rituais. Certos rituais de vodu fazem grandes empréstimos à liturgia católica. A maioria dos serviços de loa é precedida de ação de graças, um ritual católico. Em frente a um altar coberto de velas, erguido sob um dossel de rendas decoradas com imagens, o sacerdote ou sacerdotisa, no meio do seu hounsi ${ }^{24}$, recita o Padre Nosso, o Confiteor e a Ave Maria, seguidos de hinos à Virgem Maria e aos santos. A famosa oração Guinin ${ }^{25}$, que abre as cerimônias mais solenes, começa com preces católicas e invocações intermináveis aos santos; loa são chamados apenas depois (MÉTRAUX, 1958).

Além disso, os festivais de loa muitas vezes coincidem com os dos santos católicos, e esse é um dos estágios de analogia entre santos e loa (MÉTRAUX, 1958). Além disso, suas cerimônias de iniciação, ou $K a n z o^{26}$ em crioulo, geralmente acontecem no Pentecostes, um dia de iniciação cristã, isto é, o batismo dos catecúmenos, desde o nascimento até a vida sobrenatural (VERSCHUEREN, 1948).

Durante a época da Quaresma, os santuários de vodu estão fechados e nenhum serviço é celebrado. Durante a Semana Santa, os objetos da adoração do vodu são cobertos com um pano branco, como as fotos nas igrejas católicas (MÉTRAUX, 1958). Há também o batismo no vodu. Este último é adotado no vodu como um rito de consagração e é feito após a liturgia católica. As cerimônias do batismo no vodu são celebradas por um père savanne $e^{27}$; os voduístas batizam não apenas os homens, mas também os objetos de adoração (MÉTRAUX, 1958).

$\mathrm{O}$ mais conhecido dos rituais católicos misturados às práticas de vodu no Haiti é a celebração da novena, em meados de julho, de Nossa Senhora do Carmo, quando praticantes de vodu vêm de todos os cantos 
do país para participar. Devido à localização geográfica desta igreja, situada perto de uma cachoeira na cidade de Saut-d'Eau, município localizado no centro do país, esta santa é muitas vezes comparada a Ä̈da $W e ̀ d o^{28}$, uma loa das águas. No dia da festa dessa santa, uma enorme multidão de voduístas se reúne em frente à igreja construída em honra à santa de Saut-d'Eau, onde recitam orações, acendem velas, colocam flores ao pé da santa (MÉTRAUX, 1958).

$\mathrm{Na}$ religião vodu os símbolos sagrados possuem um papel fundamental nos rituais. A diversidade de objetos e seus significados serão descritos no tópico seguinte.

\section{OS SÍMBOLOS SOCIAIS DO VODU HAITIANO}

Para poder apresentar os símbolos sociais do vodu haitiano, é necessário primeiro enumerá-los, explicar suas diferentes interpretações e os diferentes contextos em que são usados. Para isso, classificaremos esses símbolos em quatro categorias: objetos, gestos, palavras e uma combinação de gestos e palavras.

$\mathrm{Na}$ categoria de objeto estão os reposoirs, os tambores e as bandeiras, que formam os objetos sagrados do vodu haitiano. Na categoria de gestos, colocamos possessão de loa, iniciação ao vodu, danças. $\mathrm{Na}$ categoria das palavras, existem as fórmulas de invocação, que com os gestos conformam as cerimônias e rituais do vodu haitiano, as orações e as canções E, finalmente, na última categoria, que é uma combinação de gesto e fala, encontramos: saudações, a cerimônia do grande loa, a invocação de loa. Fizemos uma lista não exaustiva de símbolos vodu, todavia não desenvolveremos aqui todos os rituais e utilidades desses símbolos acima mencionados.

\section{Os reposoirs no vodu haitiano}

São árvores usadas para abrigar o loa, no pátio dos houmforts. Os loa vivem lá permanentemente e essas árvores são honradas como as divindades que eles acreditam que realmente vivem lá. O loa que elas representam são alimentados em seu pedestal de alvenaria. Nichos quadrados ou triangulares são usados nesses pedestais, onde, muitas vezes, as velas são queimadas e cercadas por alimentos sagrados oferecidos em sacrifício. No meio da base, muitas vezes, há uma espécie de bacia que envolve o pé dessas árvores-reposoirs. Cerimônias muitas vezes acontecem em torno dessas árvores, bem como danças rituais. Os reposoirs são decorados e até pintados nas cores favoritas do loa em questão. Árvores de reposoirs variam de um loa para outro, um loa pode ter vários tipos de árvores reposoirs. Montes de pedras também podem servir como descanso (RIGAUD, 1953). 
Figura 1 e 2 - Cerimônias em torno de uma árvore reposoir

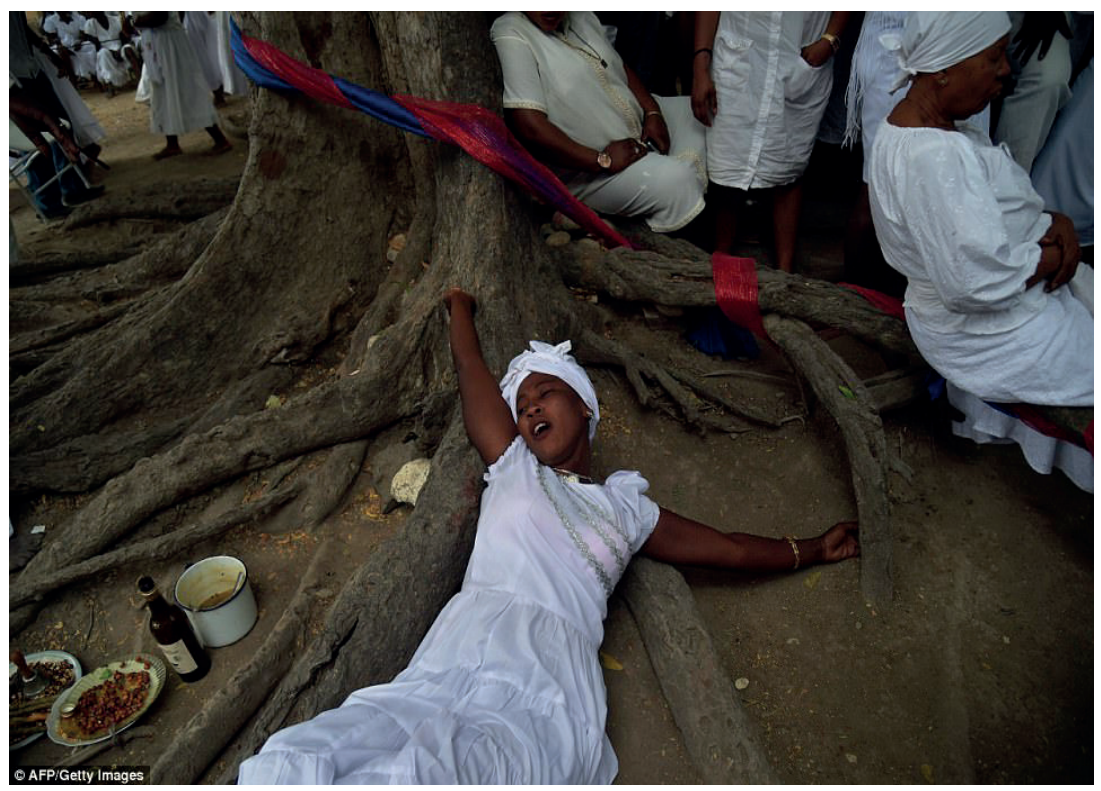

Fonte: Lakou Souvance Mystique, 2017

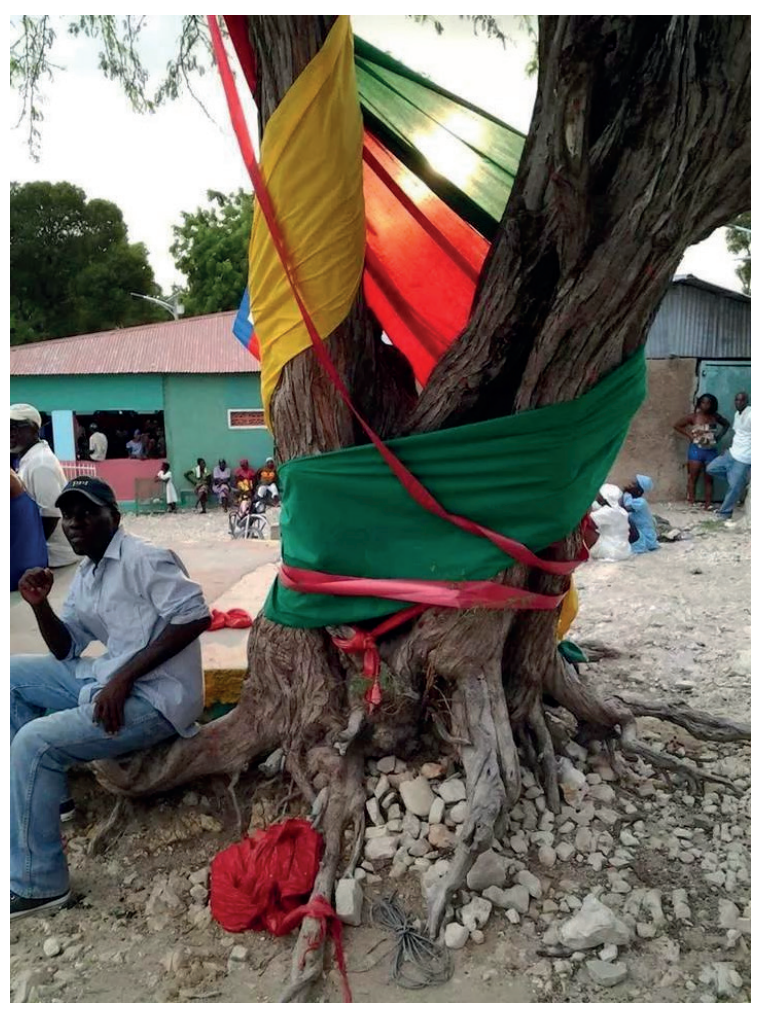

Um reposoir decorado com a bandeira do sua société

Fonte: Lakou Soukri Danach, 2014

\section{Os tambores do vodu haitiano}

Os tambores são de três tamanhos diferentes no vodu haitiano. Começando com o maior, eles são chamados, respectivamente, no rito, rada ${ }^{29}$ : manman, papai ou segundo, e boula. No rito petro ${ }^{30}$, eles levam o nome de houn, hountor e hountor-gris, a quem, às vezes, é adicionado 
um quarto nome mais formidável chamado assotor. Eles são feitos de palmeiras ocas, cobertos com pele de boi ou cabra. A batida dos tambores difere de acordo com o loa que é invocado, eles são muito sagrados no vodu haitiano e pareciam a voz do loa, esta é a razão pela qual aquelas pessoas que são possuídas pelos espíritos dançam na frente dos tambores (VERSCHUEREN, 1948).

A bênção dos tambores é feita por um houngan. Nesta cerimônia, outras cerimônias são adicionadas, tiradas dos usos da Igreja Católica e conduzidas por um père savanne. A bênção ou batismo do tambor é como o batismo de criancinhas na Igreja Católica. Durante esta cerimônia, os tambores são vestidos de branco e recebem um padrinho e uma madrinha. Os tambores às vezes são acompanhados pelo neclesin, um triângulo de ferro que bate e tem a propriedade de evocar os loa (VERSCHUEREN, 1948).

Figura 3 - Tambores do rito rada acima e tambores do rito petro abaixo

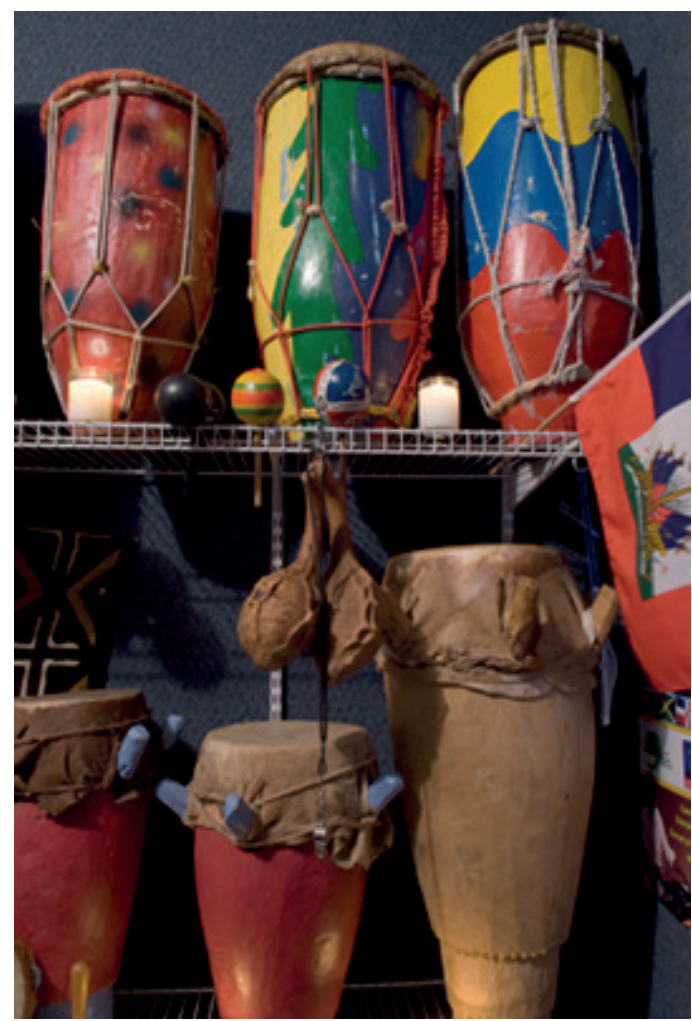

Fonte: soundkeeper Recordings, 2019

\section{Iniciação de vodu ou kanzo}

Quando uma pessoa está possuída pela primeira vez por um loa, este é chamado espírito bossal, e é derivado do bossal negro em Santo Domingo, ou seja, de escravos não batizados, não consagrados e considerados selvagens, indomados. No caso da pessoa possuída pela primeira vez, se não quisermos que esse loa chegue em momentos inoportunos, devemos batizá-lo. Daí a cerimônia de iniciação, ou kanzo, 
em crioulo. Como dissemos acima, essa cerimônia é feita em quatro graus. Antes de todas as consagrações em graus, a pessoa que foi ou é possuída por loa deve ser fechada em um quarto, o djevó ${ }^{31}$, e descansar em uma cama ou um tapete coberto com lençóis limpos; três ternos, um dos quais é novo, devem estar à sua disposição. Essas roupas serão da cor do deus que desceu sobre a pessoa. Durante o dia, os membros de sua família cantam canções de loa especiais e outras canções sob a direção do père savanne e rezam em uma sala adjacente ou fora de casa. Além disso, ao espírito é oferecido uma refeição seca, ou uma oferta sem sangue, ou seja, uma galinha com arroz; e ao mesmo tempo acendem uma lamparina a óleo ou velas brancas (VERSCHUEREN, 1948).

O batismo consiste em ser o primeiro grau dessa iniciação. No terceiro dia o batismo é administrado por um houngan ou mambo, que também deve ser possuído por um loa, "um loa deve ser batizado por outro loa” (MÉTRAUX, 1958, p. 208). Nesta ocasião, há, como para todos os batismos, um padrinho e uma madrinha. Folhas de manjericão são maceradas em água fria perfumada: neste líquido, quem realiza o batismo mergulha as mãos. Assim, enquanto hinos são ouvidos ao deus e hinos à Virgem Maria, o houngan ou a mambo lava a cabeça do candidato, que vestiu um terno novo, a possessão imediatamente segue, e o novo iniciado cai para trás, meio inconsciente, enquanto os assistentes se ajoelham e perguntam ao deus se ele está satisfeito. Quando uma resposta afirmativa chega, todos saem, e o iniciado permanece para dormir no quarto durante a noite. No dia seguinte, o novo membro vai ao oratório da casa e saúda as pessoas que o ajudaram (VERSCHUEREN, 1948).

O segundo grau consiste em conceder o grau de hounsi kanzo, isto é, um hounsi que já passou pelos ritos de iniciação (MÉTRAUX, 1958). Papai (papa) loa (houngan) está trancado em um quarto escuro onde tem uma tigela de água perto dele. Durante esse tempo, os candidatos vestidos de branco estão deitados em camas em um apartamento vizinho, também perto de um jarro de água, para capturar o loa, com o qual o houngan vai falar. Quando os mistérios (loa) tomam possessão dos eleitos, eles saem em procissão de seu descanso, carregando seus jarros na cabeça e no ombro, e vão ao entorno do santuário, onde uma multidão de pessoas está reunida, e tomam então parte nas danças animadas que estão sendo executadas. Após essa etapa, os candidatos passam pela provação judicial.

Os candidatos devem se preparar por sete dias no templo. Eles vestem uma camisola branca, e descansam em uma cama de folhas, tomando apenas frutas, leite e outros alimentos similares. Durante esse tempo, o padre lhes dá várias instruções, para informá-los das funções que terão que cumprir. No sétimo dia, que é o dia da consagração, o houngan acende a pólvora na mão de cada candidato. Então os ordenados devem, assim como o emprestador, retirar de uma caldeira fervente uma 
pequena pedra ou uma moeda que tenha sido jogada pelo houngan, e eles devem colocar o pé e a mão esquerda no fogo queimando sob panelas de farinha de milho cozido - eles tomam cuidado de antemão em untar as mãos com azeite para não se queimar. Tudo isso é acompanhado por sons de tambores e danças frenéticas, e o grito conjunto Ayibobo, que indica aprovação ou aplausos, pode resultar em "amém" ou "bravo". Este estágio também é chamado de teste de fogo (VERSCHUEREN, 1948).

$\mathrm{O}$ terceiro grau consiste na recepção do asson. Durante vários meses, o sujeito permanece na casa do professor-padre, que lhe ensina a linguagem secreta das solenidades, chamada langage - fragmentos de línguas africanas preservadas na liturgia do vodu (METRAUX, 1958). O houngan também lhe ensina como ordenar as várias cerimônias, e especialmente a arte de fazer os desenhos simbólicos de vodu, os vèvè, para as possessões (VERSCHUEREN, 1948).

Finalmente, o quarto grau, a tomada dos olhos, capacita o iniciado a ver no futuro o dom da profecia, ao qual é frequentemente acrescentado o dom de curar os enfermos. Nesse momento, o candidato estuda mais especificamente as propriedades das plantas medicinais. Os últimos dois graus são acompanhados por um juramento para não trair os segredos da sociedade. O candidato jura na cruz, para não revelar nada sobre nenhuma dessas misteriosas cerimônias (VERSCHUEREN, 1948).

\section{Danças no vodu haitiano}

A dança, que desempenha um papel importante na invocação de um loa, está tão intimamente associada à adoração loa que o vodu pode ser classificado como uma religião da dança. Este ato ritual revela forças misteriosas agindo no mundo sobrenatural. Ritmos de tambores e danças atraem os espíritos. É por isso que eles recebem um lugar de destaque em quase todas as cerimônias. Se a música e a dança agradam o loa a ponto de restringir sua vontade, é porque eles mesmos são dançarinos que se deixam levar pelo poder sobrenatural do ritmo. Cada loa tem bateria e dança própria. No vodu haitiano distinguimos as danças Daomé, Congo, Petro e Ibo. As danças evoluem sem ordem ao redor do poto-mitan, na direção oposta à das agulhas de um relógio.

Todos dançam por si mesmos, indiferentes aos vizinhos, exceto nos casos em que dois ou mais bailarinos competem com agilidade e fantasia. Toda a arte da dança é expressa menos no jogo dos pés do que nos ombros e quadris. Assim, improvisações são chamadas a cada vez que o manman tambor é batido com uma energia redobrada, e introduz no ritmo os quebrados, chamados cassé - um mini-intervalo enquanto se dança. Esses quebrados que interrompem o movimento da dança provocam um estado de paroxismo favorável às crises de loa (MÉTRAUX, 1958). 
Figura 3 - Poto-mitan

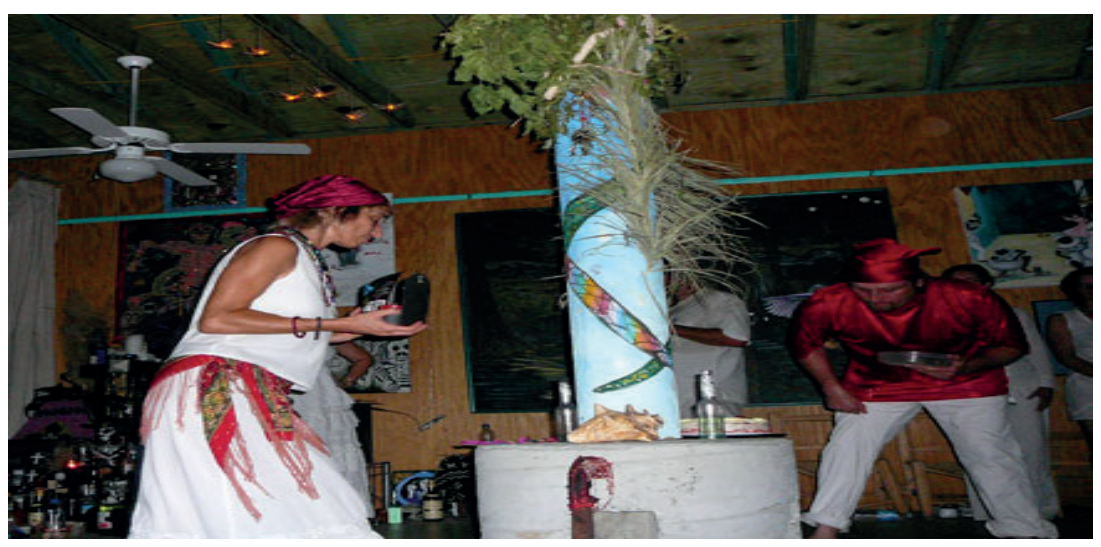

Fonte: Nathaniel sorcier vaudou (MÉTRAUX, 1958)

\section{Saudações no vodu haitiano}

$\mathrm{Na}$ iniciação, os iniciados aprendem muito sobre os rituais e knowhow do vodu, tais como: saudações, remédios foliares, utilidades de certos objetos, entre outros. No vodu há muitas formas de saudações e estas variam de acordo com as notas das pessoas que se cumprimentam. Por exemplo, a saudação entre os hounsi é segurar as duas mãos, os braços cruzados e os joelhos dobrados (MÉTRAUX, 1958). Para cumprimentos entre uma hounsi e uma mambo, a hounsi fica atrás da mambo e se vira, primeiro para a direita, depois para a esquerda e novamente para a direita. Após cada transferência, ela fará uma cassé, dobrando os joelhos e inclinando-se um pouco para trás. Finalmente, ela se curvará à mambo e dará três beijos na terra. A mambo pegará a mão da hounsi quando ela se levanta fazendo pirueta três vezes em si mesma (MÉTRAUX, 1958).

Entre os houngan, as saudações são feitas em quadrado, isto é, devem ser repetidas na direção dos quatro pontos cardeais. Então os houngan giram três vezes antes de se enfrentar. Segurando o chocalho com os braços estendidos, eles o fazem tilintar por alguns instantes, abaixamse para bater no chão com o instrumento, depois vão caminhando em direção um ao outro, pegam o braço e rodam juntos (MÉTRAUX, 1958).

Quando um houngan e uma mambo se cumprimentam, batem com a mão esquerda na palma da mão, ou esfregam as mãos, agitando suavemente o pulso. Mudanças de lugar estão no passo de dança e são seguidas por um beijo triplo na boca ou simulação de uma prostração simultânea por um beijo no chão (MÉTRAUX, 1958).

Beijo na terra é feito não apenas na frente de vèvè, de humanos e loa (pessoas ou animais possuídos), mas também na frente de objetos sagrados: o limiar do santuário, poto-mitan, tambores, vèvè etc. Sempre que em uma oração é pronunciado o nome de um loa protetor do houmfort dado, os hounsi se prostram para um beijo triplo na terra ou tocam o chão com o dedo, e então levam-no aos seus lábios (MÉTRAUX, 1958). 
O beijo da terra é feito apenas na frente de um superior, durante as saudações, se a diferença de nota não é considerável, é bom não aceitar esta homenagem e aproveitar a mão de quem quer se prostrar (MÉTRAUX, 1958).

\section{Cerimônia de grande loa hounsi}

Esta cerimônia é feita quando um grande loa entra em possessão de um dos seus fiéis. Nessa cerimônia, quando chega a hora de buscar bandeiras, dois hounsi constituem o corpo da bandeira (corps-du drapeau) e entram no houmfort sob a liderança de um homem chamado la-place ${ }^{32}$, que brande sua espada. Eles voltam para fora da casa e correm atrás do la-place, que faz bobinas com sua espada. O coral das hounsi canta uma canção para Sogbo, protetor das bandeiras. O trio se move com um passo rápido e, nos quatro pontos cardeais, saúda o poto-mitan, os tambores, os dignitários da Sociedade e os ilustres convidados. A hounsi e o la-place se curvam antes deles. No retorno das bandeiras, o hounsi é precedido do la-place, que aponta sua espada antes dele, e corre ao redor do poto-mitan enquanto faz mudanças súbitas de direção (MÉTRAUX, 1958).

\section{A invocação de loa / As fórmulas de invocação no vodu}

A coisa mais importante a ser lembrada, apesar das muitas e diferentes formas de ritual do vodu haitiano, é que todos os ritos concordam com o nome de Legba ${ }^{33}$ para introduzir outro loa. Em uma cerimônia de vodu, é preciso passar por ele para se comunicar com outro loa. Em outras palavras, é ele quem abre a barreira do loa. Portanto, todos os rituais se referem a ele porque, sem ele, toda a magia é problemática e impraticável. Todos os rituais de loa começam com uma invocação cantada a Papa-Legba. Aqui estão as primeiras palavras da canção de invocação: "papa Legba, ouvri baryè pou nou pase, lè m'tounen miap salye lwa yo" - papai, abre o portão para mim, quando eu voltar, cumprimentarei o loa (RIGAUD, 1953).

Para cada um dos grandes loa existem fórmulas de invocação que constituem um ritual oral. Estas são enumerações de nomes de santos, apelidos, frases crioulas ou langage. O uso dessas fórmulas corresponde a uma tradição africana. Um valor mágico é anexado a essas fórmulas que ajudam a fazer o loa aparecer (MÉTRAUX, 1958).

\section{CONSIDERAÇÕES FINAIS}

A cristianização foi um processo de violência contra a religião vodu e seus seguidores. Este processo, que se deu através de leis que visavam rebaixar e proibir o vodu, a fim de fazer abandonar ou impedir todas as práticas de vodu entre seus seguidores, para extingui-las. 
É um processo que foi registrado desde o período colonial francês e ainda está presente no Haiti, mas com outros exploradores que não os colonos. E, por outro lado, vimos o vodu haitiano como uma resistência do povo, que passou por muitas transformações e fez muitas concessões para sobreviver e ser praticado. E, como o medo de exploradores e pessoas antivodu, o vodu serviu como guia para o vodu muitas vezes na história haitiana.

Os símbolos sagrados revelam um todo que forma ao mesmo tempo o imaginário e a estrutura social de uma sociedade, e pode-se dizer que todos os objetos sagrados do vodu são diferentes. Eles estão cheios de significados especiais e poderes que cumprem um ou mais papéis específicos na vida dos seguidores do vodu. Regulam a hierarquia no vodu, seja entre os seguidores do vodu, seja entre os seguidores do vodu e seus deuses. Além disso, certos rituais do vodu haitiano asseguram e protegem o futuro do vodu, transmitindo os conhecimentos e certas regras do vodu de conhecedores a aprendizes.

$\mathrm{Na}$ dimensão política, vimos que o vodu serviu como guardião dos valores culturais haitianos, e de resistência contra as opressões sofridas por seus seguidores, bem como de guia para as revoltas que seus seguidores empreenderam.

Então, a sacralização dos objetos feitos pelos seguidores do vodu serve como o início de uma construção não apenas de um refúgio e resistência do vodu contra as várias formas de repressão feitas contra ele, mas também garante a sobrevivência do vodu haitiano, enquanto uma estrutura social, especificamente, de sua hierarquia, através de suas diversas manifestações e transmissões culturais.

\section{NOTAS}

1. Este artigo trata de uma parte da dissertação de mestrado intitulada "O processo de edipianização do vodu haitiano: um estudo filosófico-antropológico" orientado pelo professor Flávio Luiz de Castro Freitras e co-orientado pela professora Ana Caroline Amorim Oliveira defendido em 2020 (SUIRE, 2020).

2. O evolucionismo social e cultural é uma teoria não científica que possui como premissa que a humanidade passa por estágios (selvageria, barbárie e civilização) pressupondo uma história linear para todos os povos e culturas. Nesta teoria, os povos nativos seriam considerados selvagem e bárbaros, portanto, deveriam ser civilizados pelos povos europeus que estavam no topo da evolução. Tal teoria foi contestada metodologicamente e argumentativamente, entretanto, a mesma permeia o imaginário social enquanto uma ideologia de dominação, de branquitude e de racismo. Para aprofundar tal questão ver Raça e História (LÉVI-STRAUSS, 1976) e Colonialidade do poder, Eurocentrismo e América Latina (QUIJANO, 2005).

3. A acusação de bruxaria que ocorre na Europa nos séculos XVI-XVII retorna nas Américas e na África como justificativa religiosa da cristianização indígena e escravidão africana, identificando-os como hereges e selvagens, especialmen- 
te as mulheres nativas. A consequência econômica é a expulsão destes povos nativos de seus territórios para a expansão capitalista. Para aprofundar a relação entre a caça às bruxas e o capitalismo ver Federici (2017).

4. A maldição de Cam, que está presente no livro Gênesis, no Antigo Testamento, imposta pelo patriarca Noé ao filho de Cam, Canaã. Esta maldição foi interpretada por séculos como sendo a justificativa para a escravidão dos povos africanos. Recentemente, essa interpretação tem sido contestada em virtude dos textos bíblicos não falarem em cor de pelo ou "raça". Para mais aprofundamento desse tema ver Lotierzo (2013).

5. Um tipo de aldeia familiar que compreende dez a vinte casas e tem seu próprio cemitério. Todos os habitantes do lakou participam do desenvolvimento da terra, fora do conceito de remuneração, sob a direção da cabeceira do habitat. Este é o fundador ou membro mais antigo do lakou. Seu papel é estabelecer solidariedade entre os membros e resolver disputas (JOINT, 1999).

6. Uma herança africana do sistema de plantação colonial. Consiste em trabalhar a terra dizendo letras de algumas canções folclóricas que ajudam de certa forma os trabalhadores a fornecer o melhor deles enquanto se divertem (JOINT, 1999).

7. Os houngans [sacerdotes vodu], por sua osmose com a natureza, veneram todos os elementos, dentro os quais objetos sagrados, árvores, rios, nascentes... eles adquiriram conhecimento de cura dos elementos da flora haitiana (JOINT, 1999).

8. A arma mágica no vodu. É definido como qualquer substância, qualquer objeto ou combinação de objeto, carregado, após uma operação mágica, de uma propriedade prejudicial contra uma pessoa ou um grupo de pessoas (MÉTRAUX, 1958).

9. Encanto mágico no vodu (HURBON, 1975).

10. No vodu de hoje é um deus poderoso que é bem-vindo por soprar cargas de pó. No início, a partir do dia 17, era o todo-poderoso líder do vodu que tinha o dom de poder descobrir com os olhos, apesar de qualquer obstáculo material, tudo o que acontece a qualquer distância. A clarividência é um atributo usual entre seus seguidores (MÉTRAUX, 1958).

11. Sinônimo de veneno e envenenador. Esse nome vem de um famoso escravo marrom nativo da Guiné chamado Macandal. Durante a colonização francesa, ele semeou o terror entre os brancos, dizimando oficinas e exterminando brancos e gado, em 1757 (MÉTRAUX, 1958, p. 38-39).

12. Moeda da República do Haiti.

13. Uma palavra usada para se referir a alguém que faz coisas tolas.

14. Existem três campanhas de lutas contra o vodu no Haiti, nos anos 18961900, 1911-1912 e 1939-1942, pela Igreja Católica, com o apoio do governo haitiano, para erradicar o vodu e converter o vodu no Haiti em catolicismo em nome da civilização (CLORMÉUS, 2014).

15. Poto-mitan, em crioulo, é o pilar localizado no centro do santuário, é considerado o caminho dos loa. É um objeto muito sagrado (MÉTRAUX, 1958, p. 329). Este pilar é feito de madeira muito dura, decorado por uma faixa formada de cores diferentes, que simbolizam não só as cores do arco-íris, mas também as cobras de Dambala e Aïda Wèdo (loa de vodu) (RIGAUD, 1953).

16. "Casa loa", santuário do vodu, também chamado perystile, tonnelle ou houmfort (MÉTAUX, 1958). Cada casa tem pelo menos duas bandeiras simboli- 
zando a sociedade anexada a ela. As bandeiras são feitas de seda ou tecido de veludo, ornadas de franjas douradas e cobertas de glitter cintilante. Bordados decorativos muitas vezes desenham inscrições ou a silhueta de emblemas sagrados ou um santo identificado com algum loa e também o emblema do houmfort (MÉTRAUX, 1958).

17. Padre de vodu ainda chamado papa [papai] loa (HURBON, 1972). As mulheres que são sacerdotisas no vodu haitiano são chamadas mambo ou manman [mãe] loa.

18. Espíritos sobrenaturais no vodu haitiano. Esta palavra é geralmente traduzida como deus, divindade (MÉTRAUX, 1958, p. 329). Eles ainda são chamados de mistérios, anjos, santos, deuses, espíritos.

19. Gêmeos divinos no vodu haitiano (HURBON, 1972).

20. Ainda chamado Manger-les anges, Manger-loa, estas cerimônias destinam-se a nutrir os loa ao qual os seguidores de vodu oferecem sacrifícios de animais e vários alimentos (MÉTRAUX, 1958).

21. Cerimônia feita em homenagem ao loa (HURBON, 1972).

22. Refere-se a um houngan que pratica magia negra. Ele também é um curador (MÉTRAUX, 1958).

23. Placa de origem africana, pintada com a cor e emblemas do loa cujo alimento ou água é usado para ela (MÉTRAUX, 1958).

24. Aquele que já passou pelos ritos de iniciação que frequenta o houngan [sacerdote vodu] ou a mambo [sacerdotisa do vodu] (MÉTRAUX, 1958).

25. Guinée, em francês. Para os seguidores do vodu é o país para onde os mortos retornam, considerado como a pátria ancestral dos haitianos, onde habitam os loa (VERSCHUEREN, 1948).

26. É uma cerimônia de vodu que é feita em quatro graus: 1) lavar a cabeça, que é uma espécie de batismo; 2) promoção ao grau de ajuda do papai loa;3) a recepção do asson; 4) recepção dos olhos, para ver o futuro, ou dom da profecia (VERSCHUEREN, 1948, p. 55). O asson é um instrumento usado para chamar o loa. É feito de uma cabaça seca e esvaziada de sua polpa e suas sementes. É coberto com uma rede de pérolas de porcelana, cujo número e cor variam de acordo com os mestres de casa. Em alguns casos, as vértebras predominam. $\mathrm{O}$ asson geralmente é fornecido com um sino que o houngan soa durante a cerimônia. Existem duas categorias principais de asson: asson-mestre e asson-comum (MÉTRAUX, 1958).

27. São pessoas que aprenderam muitas orações e canções católicas em francês e latim e que cumprem o papel de sacerdote sempre que a liturgia católica incorpora o ritual do vodu. Eles são, de certo modo, os representantes da Igreja Católica no vodu (MÉTRAUX, 1958).

28. Deusa no panteão do vodu haitiano. Ela é frequentemente representada com seu marido Damballah Wèdo (outro loa) como duas cobras que parecem mergulhar em uma piscina e um arco-íris. Sendo cobras e divindades suas habitações aquáticas (árvores usadas como abrigo) estão sempre perto de rios e lagoas. Garante riqueza aos seus seguidores (MÉTRAUX, 1958).

29. Este nome é derivado da cidade de Allada [Arada] em Daomé. Este rito inclui um conjunto de rituais para loa que se originaram nesta área (MÉTRAUX, 1958). Os loa deste rito são classificados como loa legais (VERSCHUEREN, 1948).

30. Neste rito, existem loa vilões e vingativos. Esses espíritos são mais fortes e mais exigentes (VERSCHUEREN, 1948, p. 42). O rito Rada e o rito de Petro são 
os principais ritos do vodu haitiano. Mas há também outros ritos, os ritos trazem os nomes da região ancestral de origem do seus loa (VERSCHUEREN, 1948).

31 Nome do quarto de iniciação, e que representa a sepultura, a morte. Uma morte lavando o hounsi de sua vida passada feito de contaminação que este quarto é responsável pela supressão. Uma vez fora desse quarto, o hounsi passará pelo perystile para ir ao sol nascente, símbolo astral de Legba Ati-bon [um loa no vodu haitiano], para apresentar sua alma para St. Nicolas (RIGAUD, 1953). 32. Mestre de cerimônias, armado com uma espada ou um facão. Ele lidera as procissões, honra o loa e ajuda o oficiante (MÉTRAUX, 1958).

33. Loa, considerado o intérprete dos deuses (loa). Sem ele, os deuses não poderiam entender nem se comunicar com os homens (MÉTRAUX, 1958).

\section{REFERÊNCIAS}

CLORMÉUS, Lewis Ampidu. "À propos de la seconde campagne antisuperstitieuse en Haïti (1911-1912). Contribution à une historiographie". Histoire, monde et cultures religieuses, v. 4, n. 24, p. 105-130, 2012. Disponível em: <https://www.cairn.info/revue-histoire-monde-et-cultures-religieuses-2012-4-page-105.htm>. Acesso em: 20 jun. 2018.

CLORMÉUS, Lewis Ampidu. Les stratégies de luttes contre la superstition en Haïti au XIXe siècle. Journal of Haitan Studies, Santa Barbara: University of California, v. 20, n. 2, p. 104-125, 2014. Disponível em: $<$ https://muse.jhu.edu/article/576530>. Acesso em: 20 jun. 2018.

CORTEN, André. Diabolisation et mal politique. Haïti: misère et politique. Montréal: Éditions Karthala/CIDIHCA, 2000. [Édition électronique réalisé à partir de l'article original]. Disponível em: <http:// classiques.uqac.ca/contemporains/corten_andre/diabolisation_et_ mal_politique/diabolisation.html>. Acesso em: 20 jun. 2018.

COUCHARD, Françoise. Identité culturelle, religion et pratique vaudou en Haïti. Journal des anthropologues [Anthropologie \& psychanalyse], n. 64-65, p. 153-168, 1996. Disponível em: <https://www.persee. fr/docAsPDF/jda_1156-0428_1996_num_64_1_1975.pdf $>$. Acesso em: 6 set. 2019.

DANACH, Lakou soukri. Lakou Soukri, Fèt Kongo 2014. Lakou Soukri Danach Divisyon Kongo! 2014. Disponível em: <https://www. facebook.com/Lakou-Soukri-Danach-321450757963599/photos/588392687936070>. Acesso em: 14 out. 2019.

FEDERICI, Silvia. Calibã e a Bruxa: Mulheres, corpo e acumulação primitiva. São Paulo: Elefante, 2017.

FOUCHARD, Jean. Regards sur le temps passé: les marrons de la liberté. Port-au-Prince: Éditions Henri Deschamps, 1988.

FREITAS, Flávio Luiz de Castro; OLIVEIRA, Ana Caroline Amorim; SUIRE, Nikita; FAÇANHA, Luciano da Silva; CARVALHO, Zilmara de Jesus Viana de Carvalho; SOUSA, Mônica Teresa Costa. O processo de edipianizaçao do vodu haitiano: um estudo filosófico-antropológico. International Journal of Development Research, v. 10, n. 12, p. 42856-42866, 2020. 
HOFFMANN, Léon-Francois. "Le vodou sous la colonie et pendant les guerres de l'indépendance". Conjonction - Revue Franco-haïtienne, n. 173, p. 109-135, 1987. Disponível em: <http://classiques.uqac.ca/ contemporains/hoffmann_leon_francois/vodou_sous_la_colonie/ vodou_sous_la_colonie_texte.html>. Acesso em: 14 out. 2018.

HOFFMANN, Léon-Francois. Le vodou sous la colonie et pendant les guerres de l'indépendance. Conjonction: revue franco-haïtienne, $\mathrm{n}$. 173, p. 109-135, 1987. Disponível em: <http://classiques.uqac.ca/ contemporains/hoffmann_leon_francois/vodou_sous_la_colonie/ vodou_sous_la_colonietexte.html>. Acesso em: 14 out. 2018.

HOFFMANN, Léon-Francois. Haïti: couleurs, croyances, créoles. Montréal; Québec: Éditions CIDIHACA, 1989. [Édition électronique réalisé à partir de l'article original, 1989]. Disponível em: <http:// classiques.uqac.ca/contemporains/hoffmann_leon_francois/Haiti_ couleurs_croyances_creole/Haiti_couleurs_croyances_creole.pdf $>$. Acesso em: 19 out. 2019.

HURBON, Laënnec. "Racime et théologie missinnaire". Présence Africaine, n. 71, p. 35-41, 1969. Disponível em: <https://www.cairn.info/ revue-presence-africaine-1969-3-page-35.htm >. Acesso em: 3 maio 2019.

HURBON, Laënnec. Dieu dans le vaudou haïtien. Paris: Éditions Payot, 1972.

HURBON, Laënnec. Le culte du vaudou: Histoire-Pensée-Vie. Québec: Chicoutimi, 1975. [Édition électronique réalisé à partir de l’article original]. Disponível em: <http://classiques.uqac.ca/contemporains/ hurbon_laennec/culte_du_vaudou/culte_du_vaudou.html $>$. Acesso em: 20 mar. 2018.

HURBON, Laënnec. Culture et dictature en Haiti: l'imaginaire sous contrôle. Paris: Les Éditions Karthala, 1979. 203 p. Disponível em: $<$ http://classiques.uqac.ca/contemporains/hurbon_laennec/culture_et_dictature_en_Haiti/culture_et_dictature_en_Haiti.html >. Acesso em: 1 dez. 2019.

HURBON, Laënnec. Démocratisation, identité culturelle et identité nationale en Haït. Québec: Chicoutimi, 1998. [Édition électronique réalisé à partir de l'article original]. Disponível em: <http://classiques.uqac.ca/contemporains/ hurbon_laennec/democratisation_ identite_haiti/democratisation_identite_haiti.pdf $>$. Acesso em: 11 set. 2019.

HURBON, Laënnec. Le statut du vodou et l'histoire de l'anthropologie. Québec: Chicoutimi, 2005. [Édition électronique réalisé à partir de l’article original]. Disponível em: $<$ http://classiques.uqac.ca/contemporains/hurbon_laennec/statut_du_vodou_hist_anthropo/statut_ du_vodou_hist_anthropo.html>. Acesso em: 14 out. 2018.

JOINT, Gasner. Libération du vaudou dans la dynamique d'une acculturation. Roma: Éd. Ponctificia Universtà Gregoriana, 1999. 
KARSENTI, Bruno. Le symbolisme, de Durkheim à Mauss. Revue européenne des sciences sociales, v. 34, n. 105, p 93-111, 1996.

KAUSS, Saint-John. Le symbolisme des images et des couleurs dans le vaudou haïtien. Potomitan. 2015. Disponível em: <https://www.potomitan.info/kauss/symbolisme.php>. Acesso em: 05 nov. 2019.

KERBOUL, Jean. Le vaudou: magie ou religion? Paris: Éditions Robert Laffont, 1973.

LEIRIS, Michel. Les Afro-Américains. Mémoires de l'institut français d'Afrique noire, n. 27, p. 201-208, 1953.

LÉVI-STRAUSS, Claude. Raça e História. In: LÉVI-STRAUSS, Claude. Coleção Os Pensadores. São Paulo: Abril Cultural, 1976.

LOTIERZO, Tatiana Helena Pinto. Contornos do (in)visível: A redenção de Cam, racismo e estética na pintura brasileira do último Oitocentos. 2013. Dissertação (Mestrado em Antropologia Social) - Faculdade de Filosofia, Letras e Ciências Humanas, Universidade de São Paulo, São Paulo, 2013. Disponível em: <https://www.teses.usp.br/ teses/disponiveis/8/8134/tde-18122013-134956/pt-br.php>. Acesso em: 6 dez. 2021.

LOUIS XVI, Roi de France. Le code noir: édit du Roi sur les esclaves des îles de l'Amérique. Québec: Chicoutimi, 1680. [Édition électronique réalisé à partir de l'article original]. Disponível em: <http://classiques.uqac.ca/collection__documents/louis_XIV_roi_de_France/ code_noir/code_noir.html>. Acesso em: 20 mar. 2018.

MAKANDALSPEAKS. La prière de la cérémonie du Bwa Kayiman. 2015. Disponível em: <https://makandalspeaks.blogspot.com/2015/11/ bois-caiman-un-exemple-organisation nel.html>. Acesso em: 29 nov. 2019.

MARCELIN, Émile. Les grands dieux du vodou haïtien. Journal de la société des américanistes, n. 36, p. 51-135, 1947. Disponível em: <https://www.persee.fr/doc/jsa_0037-9174_1947_num_36_1_2357>. Acesso em: 19 out. 2019.

MARS, Jean Price. Ainsi parla l'oncle - essais d'ethnographie. New York: Parapsychology Foundation Inc., 1928. Disponível em: <http://classiques.uqac.ca/classiques/price_mars_jean/ainsi_parla_oncle/ainsi_parla_oncle.html >. Acesso em: 1 nov. 2019.

MÉTRAUX, Alfred. Le vaudou haïtien. Paris: Éditions Gallimard, 1958. MYSTIQUE, Lakou Souvenance. Souvnans 2017. Societe La Belle Etoile Vodoun Royal Dahomey Spirituality. 2017. Disponível em: <https:// www.facebook.com/Lakou.Souvenance/photos/pcb.1662724113757 290/1662723983757303/>. Acesso em: 14 out. 2019.

PORTO, Nuno. O museu e o arquivo do império (o terceiro império português visto do Museu do Dundo, Companhia de Diamantes de Angola). In: BASTO, Cristina; ALMDEIA, Miguel Vale; FELDMAN-BIANCO, Bela (org.). Trânsitos Coloniais: diálogos críticos luso-brasileiros. Campinas: Unicamp, 2007. 
QUIJANO, Aníbal. Colonialidade do poder, eurocentrismo e América Latina. In: LANDER, Edgardo. A colonialidade do saber: eurocentrismo e ciências sociais, perspectivas latino-americanas. Buenos Aires: CLACSO - Consejo Latinoamericano de Ciencias Sociale, 2005.

RÉPUBLIQUE D’HAÏTI. Classe des sortilèges. Code Pénal de la République d'Haïti. 1860. Disponível em: <https://www.oas.org/juridico/ $\mathrm{mla} / \mathrm{fr} / \mathrm{hti} /$ fr_hti_penal.html>. Acesso em: 15 out. 2018.

REVUE DU M.A.U.S.S., n. 8. Lobligation de donner: la découverte sociologique capitale de Mauss. La Découverte, 1996.

RIGAUD, Milo. La tradition voudoo et le voudoo haïtien: son temple, ses mystères, sa magie. Paris: Éditions Niclaus, 1953.

SIBERTIN-BLANC, Guillaume. Deleuze et l'Anti-Edipe: la production du désir. Paris: Éditions Presses Universitaires de France, 2010.

SOUNDKEEPER RECORDINGS. SR Interview: Markus Schwartz. Soundkeeper Recording, [s. 1.], 2019. Disponível em: <http://www.soundkeeperrecordings.com/interviewms.htm>. Acesso em: 1 dez. 2021.

SUIRE, Nikita. O processo de edipianização do vodu haitiano: um estudo filosófico-antropológico. Dissertação (Mestrado em Cultura e Sociedade) - Universidade Federal do Maranhão-UFMA, São Luís, 2020.

THORNTON, John K. Les racines du vaudou: religion africaine et société haïtienne dans la Saint-Domingue prérévolutionnaire. Anthropologie et sociétés. v. 22, n. 1, p. 85-103, 1998. Disponível em: <https://www.erudit.org/fr/revues/as/1998-v22-n1-as804/015523ar/>. Acesso em: 14 out. 2018.

VERSCHUEREN, J. Le culte du vaudoux en Haïti: ophiolâtrie et animisme. Paris: Ed. P. Lethielleux, 1948.

SUBMETIDO EM: 16/12/2019

APROVADO EM: 08/04/2021 